\title{
KUALITAS AIR TANAH DI SEPANJANG KALI GAJAH WONG DITINJAU DARI POLA SEBARAN ESCHERICHIA COLI (STUDI KASUS KECAMATAN UMBULHARJO)
}

\author{
Ekrar Winata, Eddy Hartantyo \\ Prodi Geofisika, Fakultas MIPA, Universitas Gadjah Mada \\ Sekip Utara, Bulaksumur 21 Yogyakarta 55281 \\ Ekrar.winata@gmail.com; hartantyo@gmail.com
}

\begin{abstract}
Abstrak - Saat ini, limbah cair dari kegiatan manusia pada umumnya langsung dibuang atau dialirkan ke sungai. Hal ini akan berdampak buruk kepada kualitas air sungai dan air sumur. Penelitian ini dilakukan untuk menentukan parameterparameter kualitas air, diantaranya adalah parameter fisik berupa suhu, parameter kimia berupa pH dan DO (Dissolved Oxigen), dan parameter biologi, yaitu bakteri E.coli pada beberapa sampel air sumur di sekitar aliran sungai Gajah Wong. Hasil analisis kehadiran golongan bakteri coli dilakukan melalui uji laboratorium di Laboratorium Hidrologi Fakultas Geografi UGM. Kandungan golongan bakteri coli di sepanjang Kali Gajah Wong sangat tinggi, sebanyak $46 \%$ penyebaran E.coli berada diatas ambang batas yaitu 2400 mg/l pada titik 1, 6, 22, 24, 25, 26, 27, 28, 29, 31, 32, 33, 34, 35, 36, 38, 40, 44, 45, 46, 48,49. Pola Sebaran E.coli semakin meningkat dari Kelurahan Bajiro sampai Kompleks Gembiraloka. Salah satu penyebabnya adalah arah aliran air Kali Gajah Wong dari utara ke selatan. Sehingga persebaran bakteri E.coli mengikuti arah aliran air. Persebaran bakteri E.coli pada lokasi penelitian dapat dilihat secara geografis denga menggunakan program Surfer.
\end{abstract}

Kata kunci: Escherichia coli, $p H, D O, M P N$, dan Surfer

\begin{abstract}
Currently, wastewater from human activities generally discarded into the river. This will have a negative impact on the quality of river water and well water. This research was done to determine the water quality parameters, physical parameters such as the temperature, the chemical parameters such as $\mathrm{pH}$ and DO (Dissolved Oxygen), and biological parameters such as E. coli bacteria in some samples of well water along Gajah Wong river. Analysis coli bacteria was conducted by laboratory testing at the Hydrologic Laboratory, Gadjah Mada University. Along Gajah Wong river, Coli bacteria content is very high, as much as 46\% from the distribution of E.coli were $2400 \mathrm{mg} / \mathrm{l}$ at point 1, 6, 22, 24, 25, 26, 27, 28, 29, 31, 32, 33, 34, 35, 36, 38, 40, 44 , 45, 46, 48.49. The Distribution pattern of E.coli increasing from Bajirao to Gembira Loka Zoo. This is caused by water flow from north to south. So, the distribution of E.coli follows the water flow and can be viewed geographically with Surfer.
\end{abstract}

Key words: Escherichia coli, $p H, D O, M P N$, and Surfer

\section{PENDAHULUAN}

Air merupakan sumber kehidupan yang dibutuhkan oleh semua mahluk hidup. Jumlah air yang terdapat di permukaan bumi lebih kurang $1.36 \times 1018 \mathrm{~m}^{3}$, terdiri atas air asin dan air tawar. Air tawar yang jumlahnya hanya $3 \%$ terdapat dalam berbagai wujud dan lingkungan yaitu berupa salju / es di kutub (75\%); air tanah (24\%); air permukaan $(0.065 \%)$; berupa awan, kabut, embun $(0.0035 \%)$ dan air hujan $(0.03 \%)$ Jumlah air tawar di permukaan bumi relatif tetap, distribusinya menurut ruang dan waktu mengikuti siklus hidrologi [1].

Menyadari pentingnya air bagi manusia, maka penggunaan air yang tidak memenuhi kriteria standar kualitas (Tabel 1) sesuai peruntukannya dapat menimbulkan gangguan terhadap kesehatan yang diakibatkan oleh adanya mikroorganisme patogen, zat kimia beracun dan zat radioaktif. Salah satu penyakit yang diakibatkan kurangnya ketersediaan air bersih adalah diare. Diare adalah penyakit yang ditandai dengan bertambahnya frekuensi buang air besar lebih dari biasanya (lebih dari 3 kali per hari) disertai perubahan bentuk dan konsistensi tinja. Diare disebabkan infeksi bakteri di dalam saluran pencernaan, seperti Escherichia coli. [1]

Tabel 1. Kualitas air bersih

\begin{tabular}{|l|c|}
\hline \multicolumn{1}{|c|}{ Kelas kualitas } & Koliform total \\
\hline A (baik) & $\leq 50$ \\
\hline B (kurang baik) & $51-100$ \\
\hline C (jelek) & $101-1000$ \\
\hline D (amat jelek) & $1001-2400$ \\
\hline E (sangat amat jelek) & $>2400$ \\
\hline
\end{tabular}


Sumber : Direktorat Jenderal P2M dan PLP (1995)

Fungsi penting ini menjadi salah satu alasan pentingnya menjaga air sungai dari pencemaran yang dapat menjadi sumber berbagai penyakit. Studi yang dilakukan pada air sungai di Yogyakarta yaitu sungai Code, Winongo, dan Gajah Wong menunjukkan Kualitas air telah mengalami penurunan. Ketiga sungai yang diteliti tergolong kedalam kelas II atau III atas dasar beberapa parameter penentu kualitas air sesuai dengan PP 82 Tahun 2001 [2]. Dari hasil penelitian tersebut menunjukkan bahwa kulaitas air sungai di Yogyakarta tidak layak untuk digunakan dalam kegiatan rumah tangga.

Atas dasar kondisi di atas maka dilakukan penelitian mengenai kualitas air tanah secara bakteriologis yang dikaitkan dengan keadaan sanitasi lingkungan sekitar serta mengukur pola distribusi Escherichia coli di Sepanjang kali Gajah wong.

Daerah Aliran Gajahwong sebagian besar dimanfaatkan untuk berbagai kegiatan domestik, industri, dan pertanian. Limbah dari kegiatan-kegiatan tersebut yang umumnya langsung dibuang ke dalam sungai dan akan berdampak sangat buruk terhadap kualitas air sungai-sungai tersebut. Dampak buruk terhadap kualitas air sungai tergantung dari jenis, jumlah dan sifat dari limbah yang masuk ke dalam sungai.

Pada penelitian sebelumnya [4] menggunakan analisa penerapan metode volume hingga untuk mengestimasi kadar pencemaran air yang terjadi pada sungai dengan menggunakan data pada titik monitoring sungai yang jumlahnya terbatas. selain itu telah dilakukan penelitian [3] mengenai kualitas air tanah di kecamatan tebet jakarta selatan ditinjau dari pola sebaran escherichia coli.

Pada penelitian ini, akan dilakukan uji E.coli berdasarkan Parameter fisik yang diukur, yaitu suhu, parameter kimia, yaitu $\mathrm{pH}$ dan $\mathrm{DO}$ dan parameter biologi, yaitu bakteri E. coli. Pemeriksaan kandungan Bakteri E. coli pada air tanah di sepanjang kali gajah wong kecamatan umbulharjo kelurahan Pandeyan menggunakan metode Most Probable Number (MPN) dan penyaringan dengan membran yang mengacu pada SNI 01-2332-1991.

\section{METODE PENELITIAN/EKSPERIMEN}

Penelitian ini termasuk dalam penelitian penerapan. Metode yang digunakan dalam penelitian ini adalah dengan mengumpulkan informasi baik dari buku atau jurnal yang berkaitan dengan metode MPN dan menerapkannya untuk pemeriksaan pencemaran air tanah yang mengandung E.coli di sepanjang sungai Gajahwong serta mensimulasikan peta pencemaran air tanah dengan bantuan surfer.

Penelitian dilakukan pada tanggal 10 November 2012. Pengambilan sampel air tanah dilakukan di sumur resapan atau sumur air bawah tanah masyarakat Kabupaten Umbulharjo. Uji sampel dilakukan di laboratorium Hidrologi Fakultas Geografi Universitas Gadjah Mada.
Beriku adalah skema kerja dari penelitian penyebaran bakteri E.coli di kali Gajah Wong (Gambar 1)

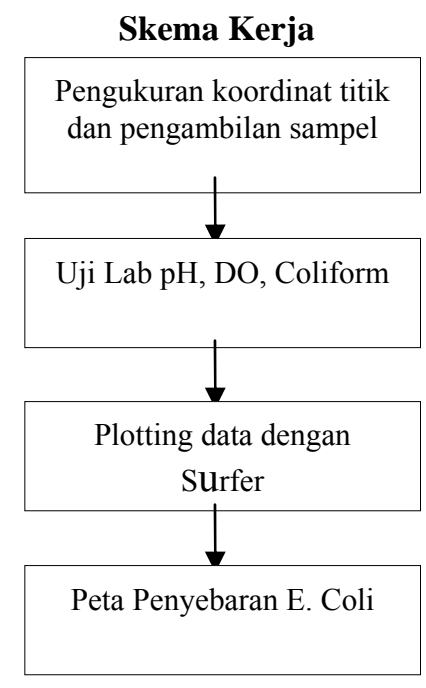

\section{Gambar 1. Skema Kerja \\ PENGAMBILAN SAMPEL AIR}

Pengambilan sampel air tanah, pengambilan contoh untuk uji kualitas air dengan tata cara sebagai berikut: Siapkan alat pengambilan contoh sesuai jenis air yang akan diuji; Bilas alat dengan contoh yang akan diambil sebanyak tiga kali; Ambil contoh sesuai peruntukan analisis;Masukkan kedalam wadah yang sesuai peruntukan analisis.

\section{PENENTUAN JUMLAH TITIK SAMPLING}

Untuk menentukan jumlah titik sampling digunakan teknik cluster random sampling. kelompok-kelompok sampel tersebut dibagi atas 5 kelurahan yang ada di kecamatan umbulharjo, yaitu umbulharjo kelurahan semaki kelurahan warungboto kelurahan pandeyan kelurahan sorosutan kelurahan giwangan kelurahan muja-muju kelurahan tahunan.

\section{PLOTTING DATA KE SOFTWARE SURFER}

Perangkat lunak ini melakukan plotting data tabular XYZ tak beraturan. Grid adalah serangkaian garis vertikal dan horisontal yang dalam surfer berbentuk segi empat dan digunakan sebagai dasar pembeentukan kontur dan surface tiga dimensi. Garis vertikal dan horisontal ini memiliki perpotongan. Pada perpotongan ini disimpan nilai $\mathrm{z}$ yang berupa titik ketinggian atau kedalaman. gridding merupakan proses pembentukan rangkaian nilai $\mathrm{Z}$ yang teratur dari sebuah data XYZ. Hasil dari proses gridding ini adalah file grid yang tersimpan pada file.grd.

\section{HASIL DAN PEMBAHASAN}

Dari kegiatan interview diketahui bahwa $24 \%$ dari kedalaman sumur penduduk berada pada kedalaman 10 meter, dan $12 \%$ dari kedalaman sumur penduduk berada pada kedalaman 7,8, dam 15 meter. Seperti yang dilihatkan pada grafik 1 . 


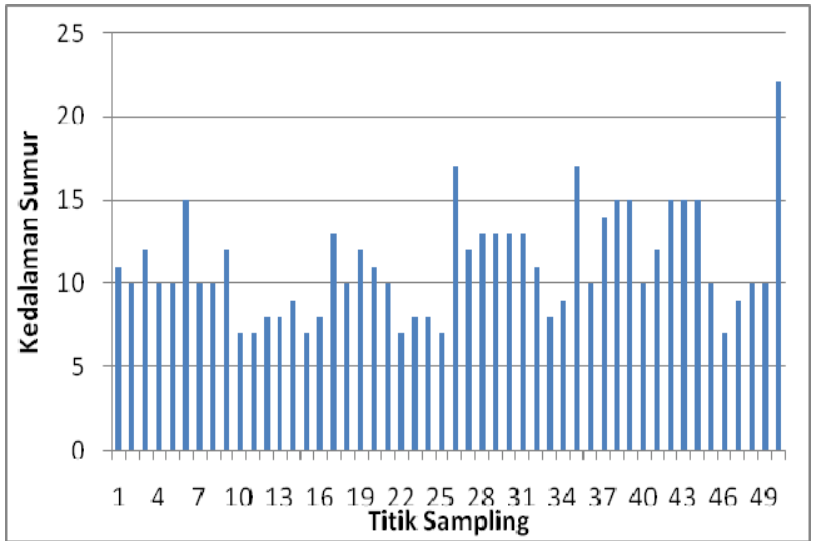

Grafik 1. Kedalaman air sumur penduduk

Kedalaman air sumur penduduk di dekat Kali Gajah Wong ini sangat bervariasi. Sumur yang paling dalam terletak pada kedalaman 22 meter yaitu dititik 50. Sedangkan yang paling rendah ada pada kedalaman 7 meter yaitu pada titik 10, 11, 15, 22, 26, dan 46. Berikut adalah penyebaran kedalaman air sumur penduduk di Kali Gajah Wong. Lokasi pengmabilan air sumur dapat dilihat pada gambar 3 dibawah ini.

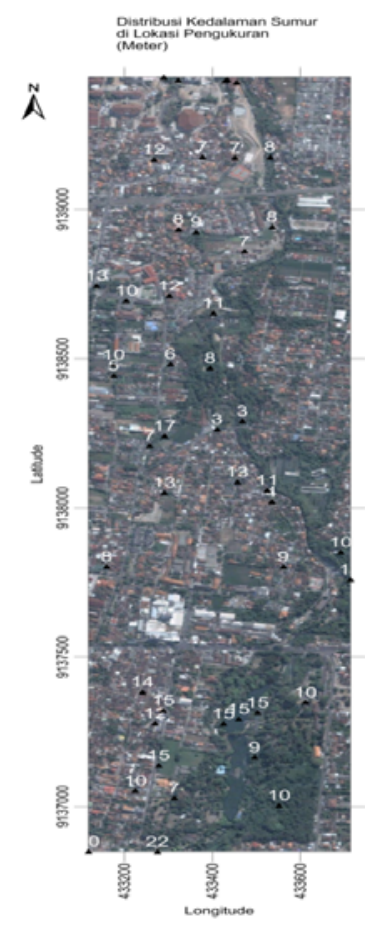

Gambar 2. Lokasi pengambilan sampel air sumur

Lokasi pengambilan titik sampiling sebanyak 50 titik yang tersebar sepanjang Subdas Kali Gajah Wong. Pemilihan 50 titik di sepanjang Kali Gajah Wong Umbulharjo ini dengan alasan besarnya penyebaran E.coli pada aliran sungai. Hasil pengukuran suhu pada sampling air sumur pada 50 lokasi pengambilan dapat dilihat pada grafik 2 dibawah ini.

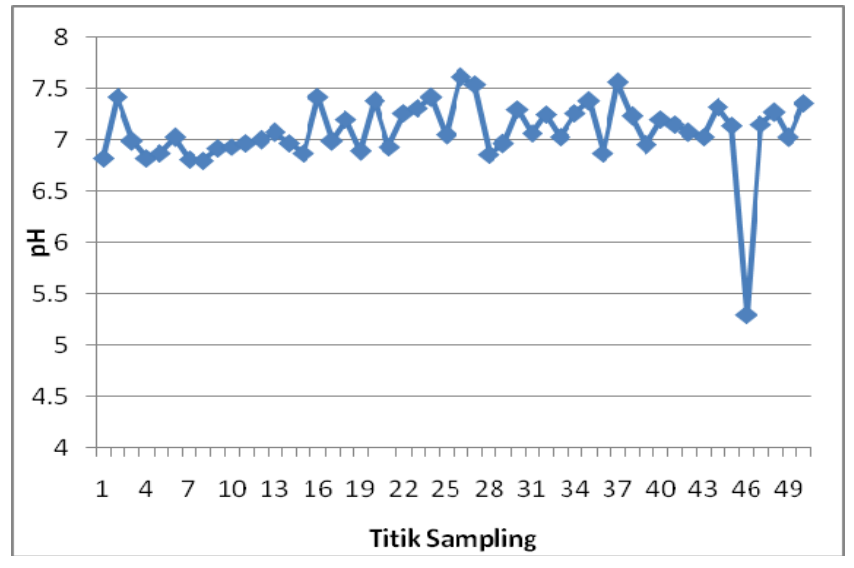

Grafik $2 \mathrm{pH}$ air sumur

Nilai pH pengukuran in situ antara 5,3-7,61. Menandakan $\mathrm{pH}$ air tanah telah mendekati kadar asam, karena batas nilai $\mathrm{pH}$ normal untuk air tanah adalah 6 sampai dengan 8,5[18].Nilai pH tertinggi ada di titik 26 yaitu 7,61. Sedangkan untuk nilai $\mathrm{pH}$ terendah berada pada titik 46, yaitu 5,3. Hasil pengukuran DO pada pengambilan sample dapat dilihat pada grafik 3 dibawah ini.

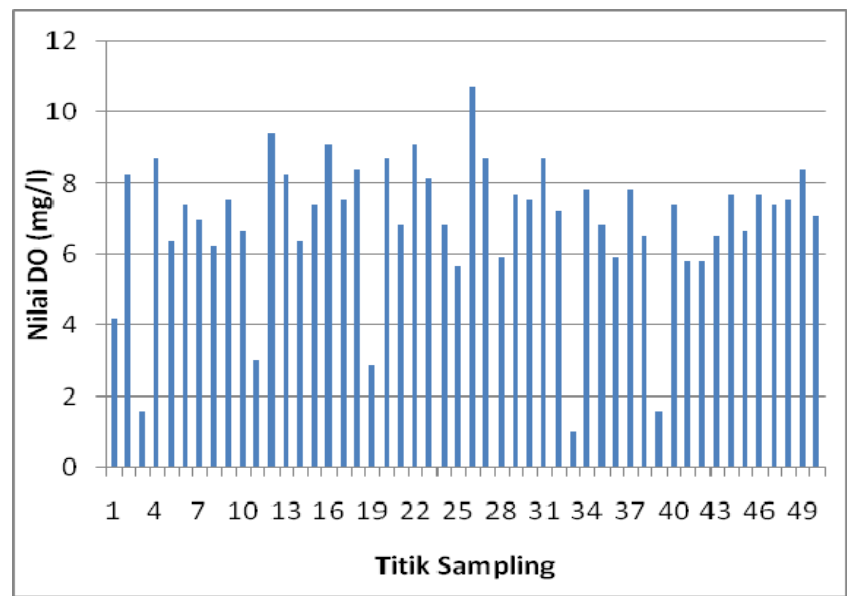

Grafik 3 Nilai DO Sample air sumur

Kandungan DO yang tercatat antara 1,01 sampai 10,72. DO tertinggi ada pada titik sampling 26 sedangkan DO yang paling rendah sebesar 1,01 ada pada titik sampling 33. Hasil analisis kehadiran golongan bakteri coli adalah melalui uji coliform. Pada penelitian ini dilakukan uji laboratorium di Laboratorium Hidrologi Fakultas Geografi UGM. Pada tabel 4 diatas adalah data uji coliform untuk penyebaran bakteri coli di sepanjang Kali Gajah Wong. Kandungan golongan bakteri coli di sepanjang Kali Gajah Wong sangat tinggi, sebanyak $46 \%$ penyebaran E.coli berada diatas ambang batas yaitu $2400 \mathrm{mg} / \mathrm{l}$ yaitu ada pada titik 1, 6, 22, 24, 25, 26, $27,28,29,31,32,33,34,35,36,38,40,44,45,46,48,49$. 
Sedangkan kandungan paling rendah sebanyak $2 \%$ pada kandungan 4, 75, dan $150 \mathrm{mg} / \mathrm{l}$. Persebaran bakteri E.coli pada lokasi penelitian dapat dilihat secara geografis denga menggunakan program Surfer (Gambar 3).

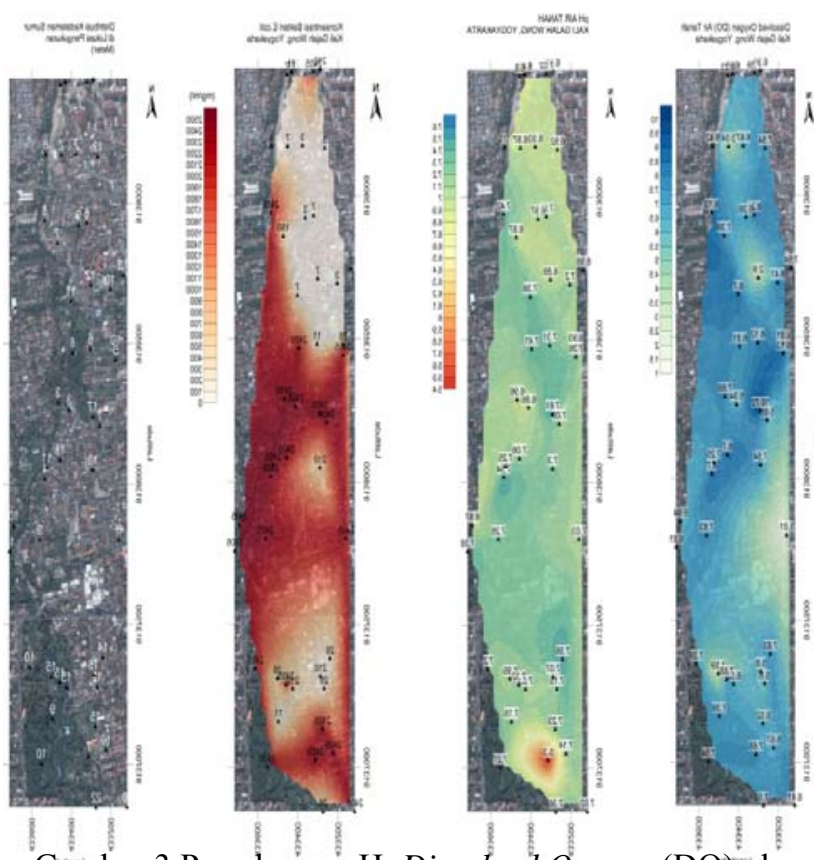

Gambar 3 Persebaran pH, Dissolved Oxygen (DO), dan Coliform pada air sumur Kali gajah Wong

Peta diatas merupakan kenampakan geografis persebaran DO untuk peta dengan gradasi warna biru. Penyebaran $\mathrm{pH}$ pada air sumur untuk peta grdasi warna hijau. Dan peta gradasi warna merah adalah persebaran Bakteri E.coli. Peta persebaran Dissolved Oxygen (DO) dengan gradasi warna biru. DO dengan nilai yang tinggi ditunjukkan oleh warna biru tua dengan nilai 10,72 terdapat di kelurahan Babatan. Sedangkan semakin mendekati warna hijau nilai kelarutan oksigen semakin rendah dengan nilai 1,01 terdapat di Kelurahan Sidobali.

Peta dengan gradasi warna biru-merah menunjukkan persebaran tinggi $\mathrm{pH}$ air tanah di sepanjang Kali Gajah Wong Umbulharjo. Warna biru menunjukkan nilai $\mathrm{pH}$ yang basa dengan nilai tertinggi 7,61 pada Kelurahan Babatan selain itu semakin menunjukkan warna merah $\mathrm{pH}$ akan semakin asam dengan nilai 5,3 di kawasan Gembiraloka. Peta dengan gradasi warna merah menunjukkan persebaran Bakteri E.coli. persebaran E.coli ini diselidiki dengan analisis uji lab coliform di Laboratorium Hidrologi fakultas Geografi UGM. Terlihat tingkat persebaran bakteri E.coli yang sangat tinggi dengan nilai $2400 \mathrm{mg} / \mathrm{l}$ pada daerah Kelurahan Babatan sampai Kelurahan Babadan.

Faktor yang dapat menyebabkan persebaran E.coli yang sangat tinggi pada daerah Kelurahan Babatan-Babadan adalah jenis tanahnya adalah alluvial dengan lapisan lempung Pada umumnya jenis tanah alluvial memiliki tingkat porositas tinggi tetapi daya perkolasi dan permeabilitasnya rendah sehingga sulit mengalami proses filtrasi alami oleh tanah dan bakteri $E$. coli di air tanah tersebut cenderung bergerak secara vertikal.

\section{KESIMPULAN}

1. Kandungan golongan bakteri coli di sepanjang Kali Gajah Wong sangat tinggi, sebanyak $46 \%$ penyebaran E.coli berada diatas ambang batas yaitu $2400 \mathrm{mg} / \mathrm{l}$ yaitu ada pada titik 1, 6, 22, 24, 25, 26, 27, 28, 29, 31, 32, 33, $34,35,36,38,40,44,45,46,48,49$. Sedangkan kandungan paling rendah sebanyak $2 \%$ pada kandungan 4, 75, dan $150 \mathrm{mg} / \mathrm{l}$.

2. Kandungan DO yang tercatat antara 1,01 sampai 10,72. DO tertinggi ada pada titik sampling 26 sedangkan DO yang paling rendah sebesar 1,01 ada pada titik sampling 33.

3. Nilai $\mathrm{pH}$ pengukuran in situ antara 5,3-7,61. Menandakan $\mathrm{pH}$ air tanah telah mendekati kadar asam, karena batas nilai $\mathrm{pH}$ normal untuk air tanah adalah 6 sampai dengan 8,5. Nilai $\mathrm{pH}$ tertinggi ada di titik 26 yaitu 7,61. Sedangkan untuk nilai $\mathrm{pH}$ terendah berada pada titik 46, yaitu 5,3.

4. Pola Sebaran E.coli semakin meningkat dari Kelurahan Bajiro sampai Kompleks Gembiraloka. Salah satu penyebabnya adalah arah aliran air Kali Gajah Wong dari utara ke selatan. Sehingga persebaran bakteri E.coli mengikuti arah aliran air.

\section{UCAPAN TERIMA KASIH}

Penulis mengucapkan puji syukur kehadirat Allah SWT yang telah memberikan kekuatan dan kesempatan kepada penulis sehingga dapat menyeleseaikan penelitian ini dan penulis juga mengucapkan terimakasih kepada LPPM UGM yang telah membantu penulis dengan membrikan batuan baik berupa materi atauun non materi sehingga terselesaikan makalah ini dapat terwujud.

\section{PUSTAKA}

[1] Temenggung, Muhtadi Arsyat, Penggunaan Sumur Dangkal Sebagai Penyedian Air Nersih Dan Hubungannya Dengan Kesakitan Diare. Tesis, Institut Pertanian Bogor, Bogor, 2004

[2] Syamsul A Siradz, Endra Setyo H, dam Ismi, Kualitas Air Sungai Code, Winongo Dan Gajahwong, Daerah Istimewa Yogyakarta, Jurnal Ilmu Tanah dan Lingkungan Vol. 8, No. 2 (2008) p: 121-125.

[3] Rahayu, Budi, Kualitas Air Tanah di Kecamatan Tebet Jakarta Selatan Ditinjau dari Pola Sebaran Escherichia coli, Tesis, Universitas Tri sakti, Jakarta, 2009.

[4] Yuli, Fitriana, Penerapan Estimasi Kalman Filter untuk Mengetahui Pencemaran Air Sungai di Kali Gajah Wong, Tesis, Universitas Negeri Yogyakarta, Yogyakarta, 2010. 